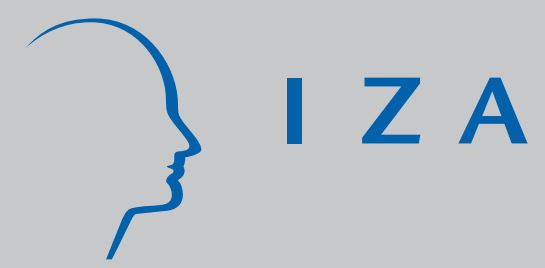

IZA DP No. 10382

My Baby Takes the Morning Train:

Gender Identity, Fairness, and Relative Labor Supply

Within Households

Anthony Lepinteur

Sarah Fleche

Nattavudh Powdthavee

November 2016 


\title{
My Baby Takes the Morning Train: Gender Identity, Fairness, and Relative Labor Supply Within Households
}

\author{
Anthony Lepinteur \\ Paris School of Economics \\ Sarah Fleche \\ CEP, London School of Economics \\ Nattavudh Powdthavee \\ Warwick Business School, \\ CEP, London School of Economics and IZA
}

\section{Discussion Paper No. 10382 \\ November 2016}

\author{
IZA \\ P.O. Box 7240 \\ 53072 Bonn \\ Germany \\ Phone: +49-228-3894-0 \\ Fax: +49-228-3894-180 \\ E-mail: iza@iza.org
}

\begin{abstract}
Any opinions expressed here are those of the author(s) and not those of IZA. Research published in this series may include views on policy, but the institute itself takes no institutional policy positions. The IZA research network is committed to the IZA Guiding Principles of Research Integrity.

The Institute for the Study of Labor (IZA) in Bonn is a local and virtual international research center and a place of communication between science, politics and business. IZA is an independent nonprofit organization supported by Deutsche Post Foundation. The center is associated with the University of Bonn and offers a stimulating research environment through its international network, workshops and conferences, data service, project support, research visits and doctoral program. IZA engages in (i) original and internationally competitive research in all fields of labor economics, (ii) development of policy concepts, and (iii) dissemination of research results and concepts to the interested public.
\end{abstract}

IZA Discussion Papers often represent preliminary work and are circulated to encourage discussion. Citation of such a paper should account for its provisional character. A revised version may be available directly from the author. 
IZA Discussion Paper No. 10382

November 2016

\section{ABSTRACT \\ My Baby Takes the Morning Train: Gender Identity, Fairness, and Relative Labor Supply Within Households}

The current study argues that women's decision to leave the labor force at the point where their income exceeds their husbands' income may have less to do with gender identity norm (Bertrand et al., 2015) and more to do with what women think is a fair distribution of relative working hours within the household. Using three nationally-representative data, we show that life satisfaction is significantly lower among women whose work hours exceed their partners, holding the share of wife's income constant. Men, by contrast, are not affected by working longer or fewer hours than their wives.

JEL Classification: $\quad$ I31, J12, J22

Keywords: fairness, gender identity, life satisfaction, relative income, working hours, labor supply

Corresponding author:

Nattavudh Powdthavee

Centre for Economic Performance,

London School of Economics \& Political Science

Houghton Street,

London, WC2A 2AE

United Kingdom

E-mail: n.powdthavee@lse.ac.uk 


\section{Introduction}

In a recent path-breaking study of gender identity and relative income within households, Marianne Bertrand, Emir Kamenica, and Jessica Pan (2015) show that women in the United States are significantly more likely to opt out from the labor market altogether when their earning potential exceeds that of their husbands', either that or find a job that earns less than their potential if they decide to work. According to the authors, this seemingly counterintuitive behavior is mainly explained by the fact that many women prefer not to go against certain gender-specific behavioral prescriptions - more specifically, that "a man should earn more than his wife" because doing so could be inherently costly for them (Akerlof and Kranton, 2000, 2010). The penalty on women's livelihood for violating the gender identity norm is also reported in their study, in which they show that women who earn more than their husbands are more likely to be less satisfied with their married life, spend more time doing household chores (presumably because they feel guilty for having earned more than their husbands), and are therefore more likely to divorce as a result of working this "second shift" (Hochschild and Machung, 1989).

While it may be clear from Bertrand et al.'s study that a violation of the gender identity norm is likely to be significantly costly for women, the underlying mechanisms that drive these results continue to be imperfectly understood. For example, to what extent can we attribute a wife's decision to reduce her labor supply when she has the potential to earn more than her husband, or to do relatively more household chores when she does earn more, to the psychological effect of her not wanting to feel more threatening to her spouse? What explains why the wife should continue to feel significantly less satisfied with her marriage if she is able to compensate the feeling of guilt by doing relatively more household chores than she would otherwise? What are the implications of gender identity on husband's satisfaction and behavior when he goes against his own gender norm by earning relatively less than his wife, e.g., can we expect the husband to want to do relatively more household chores when he has the potential to earn less than his wife because he feels guilty? These are difficult questions, but they seem important for the understanding of the mechanisms behind the apparent gender identity effect on women's decision to participate in the labor market. 
Building upon Bertrand et al.'s (2015) work, we aim to provide a more complete picture of the underlying mechanisms that drive their study's results. We argue that, in a modern society, a wife whose income exceeds that of her husband's chooses to reduce her labor supply or do relatively more household chores not primarily because she feels guilty for violating the gender norm "man should earn more than his wife". Rather, she does so because, by assumption

- there is pay discrimination against women,

- compared to other groups, women who choose to adopt the identity of a "career woman" are generally more egalitarian in attitudes, and

- men who work less hours than their wives contribute less than what their wives expected them to contribute in terms of household chores.

What these three assumptions transpire is that women would generally be more inclined to leave the labor force when her potential earning is the same as or greater than their husbands. Yet, they do this not primarily because they do not want to appear threatening to their husbands, but rather because they feel that it is unfair for them that they have to work significantly longer hours than their husbands just to be able to earn at least the same income as they do. And when they do earn the same or more than their husbands, women have little choice but to come home and work a "second shift" simply because no significant attempts would have been made by the husbands to compensate their wives for working less number of hours than they do. ${ }^{2}$

Put simply, we propose that it might not be so much out of guilt but out of concerns for fairness that drive women who earn the same or more than their spouses to leave the labor force altogether, and in some cases to a dissatisfied marriage and a family breakdown.

Using nationally representative random samples of employed men and women in America, we show that neither men nor women are significantly more or less satisfied with their life from earning a relatively higher income than their spouse, which is inconsistent with the gender identity and relative income hypothesis. However, we document evidence that, holding own work hours, own income, and relative income within the household constant, women and not men tend to

\footnotetext{
${ }^{2}$ This is equivalent to saying that a wife is unlikely to feel significantly guilty for out-earning her husband so long as she could work the same number of hours as he does, or work relatively longer hours as long as her husband could contribute a comparatively "fair" amount of household work in order to compensate for the relatively shorter work hours that he puts in.
} 
experience a statistically significantly lower overall life satisfaction from working relatively longer hours than their husbands. This finding is robust to the instrumental variables (IV) regression estimation. We also report corroborative results for a British and a German panel, which gives us the opportunity to observe the within-person changes in life satisfaction of people before and after they start working relatively longer hours than their spouse.

The current study also shows that, while men whose wives work relatively longer hours have been shown to be generally egalitarian in their attitudes, there is little evidence of them "stepping up" and increasing the number of hours that they spend on household chores on a weekly basis. At the same time, we also find little evidence to suggest that women who work relatively longer hours than their husbands spend significantly more or less time doing household chores than other women, on average. Finally, we show that relative working hours is not only an important independent predictor of future divorce, but also a significantly more robust predictor than relative income within the household of a wife's decision to quit her current job and/or leave the labor force altogether one period into the future in both German and British panels.

\section{Background}

Standard economic theories of the marriage market, notably Gary Becker's seminal work in the early 1970s (Becker, 1973, 1974), assume that, in the case of increasing returns to specialization, it is more efficient for one spouse to specialize in market production and for the other to specialize in home production. This is because the spouse who devotes more time in market production will accumulate specific marketspecific human capital, which in turn raises his or her productivity and wages. However, both spouses may choose to participate in the labor market when returns are decreasing, and the division of labor and domestic work will then be determined by their relative productivity in those two activities. Although Becker's model is gender neutral, it is usually the case that men will tend to spend more time at the workplace because they are relatively more productive in market production, while women will tend to spend more time at home because they are relatively more productive in home production. 
While standard Beckerian models offers an explanation for the observed relative income within households, which is normally caused by men spending more time in market production than women, these models do not explain why there is a sharp, discontinuous drop in the distribution of married couples in the United States at the point where the wife starts to earn more than the husband. Using the Census Bureau Data, Bertrand et al. (2015) show that the drop in the distribution of married couples at the point where the wife's income is the same as the husband's is estimated to be around $14 \%$ across all married couples, and $11 \%$ for married couples who have been married for more than 10 years. According to the authors, the discontinuity in the marriage rates at equal incomes is driven by gender identity norms; that is, because couples traditionally dislike unions where wives earn more than husbands, as women's income increases, the marriage rates will inevitably fall. They also show that, in couples where the wife's potential income is likely to exceed the husband's, the wife is likely to leave the labor market or find a job that earns less than her potential if she decides to work so as to appear less threatening to her husband. In addition to this, they also present evidence that wives who violate the gender identity norms by earning more than their husbands are more likely to be less satisfied with their married life, spend more time doing household chores perhaps because they feel guilty for earning relatively higher incomes, and are therefore more likely to divorce. The current study, however, argues that there may be alternative explanations to Bertrand et al.'s findings other than women not wanting to violate the gender identity norm "man should earn more than his wife".

For example, despite evidence of a dip in adults' attitudes toward working women during the mid 1990s, people's preferences for egalitarianism within the household have remained very high throughout the end of 1990s, 2000s, and 2010s, with almost $80 \%$ of the US and European population agreeing in the recent surveys that women should have the same opportunity for securing a job as men (see, e.g., Fortin, 2005; Cotter et al., 2011; Farré and Vella, 2013; Apino et al., 2015). ${ }^{3}$

\footnotetext{
${ }^{3}$ Cotter et al. (2011) find that by 2008 over $70 \%$ of the population agree that a working mother can establish just as warm and secure a relationship with her children as a mother who does not work; over $65 \%$ disagree that It is much better for everyone involved if the man is the achiever outside the home and the woman takes care of the home and family; and also $65 \%$ disagree that preschool child is likely to suffer if his or her mother works. Using the World Values Surveys, Fortin (2005) shows that, on average, almost $80 \%$ of people surveyed in the OECD countries do not believe that scarce jobs should go to men first, and approximately $78 \%$ believe that both husband and wife should contribute to household income.
} 
Regarding the recent stagnation in gender attitudes in the US, Cotter et al. (2011) concludes that the phenomenon is more likely the consequence of the rise of an "egalitarian essentialism". More specifically,

\begin{abstract}
These 1990s popular culture themes of intensive mothering and women's career stress supported some traditional gender roles by justifying women's decisions to forgo careers and stay home to raise their children. But the traditional stay-at-home role was justified not for the sake of their husband's careers but for their children's advancement and for their own mental health. Thus, the new gender frame could still be technically egalitarian between husband and wife and even emphasize the importance of women's autonomous choices but nevertheless support what still looks like a traditional gender division of labor. [A dip in gender attitudes] could therefore be reinterpreted in the 1990s not as an endorsement of hierarchical gender relations of submissive wives and decision-making husbands but as a sensible choice for women to maximize their own and their children's best interests. (p. 285).
\end{abstract}

What these sociological studies seem to suggest is that, at least in recent times, the majority of the US and European population - especially women who choose to work and earn relatively higher income than men - are generally egalitarian in attitudes, which inevitably cast some doubts over whether the sharp discontinuity in women's labor supply at the point where relative income is $1 / 2$ in America during the mid-1990s is due primarily to their preferences of not wanting to violate the traditional gender identity norms. But if not for this reason, then what explains women's decision to reduce their labor supply at the point where their ability to earn exceeds that of their husbands'?

Our hypothesis is that the women's behaviors found in Bertrand et al.'s study are not driven by their relative income concerns - in that they have strong preferences for not wanting to out-earn their husbands - but rather by their concerns for the unfair distribution of relative working hours within the household at the point where relative income is $1 / 2$. As an aid to our thinking, assume a world in which women who work are paid lower wages than men with similar observable characteristics for the same amount of work ${ }^{4}$. In this world, women will have to work significantly longer hours

\footnotetext{
${ }^{4}$ Although the gender pay gap is slowly converging over time, women are still ceteris paribus paid less than men who share the same observable characteristics (e.g., Blau and Kahn, 1992, 2006, 2007; Altonji and Blank, 1999; Jarrell and Stanley, 2004).
} 
than men just to be able to earn the same level of income. In couples where the wife cares deeply about gender wage fairness, she may find it more optimal to quit the labor force altogether or reduce her labor supply when her potential earning is the same as the husband's. This is so that she does not have to feel "resentful" towards her husband for having to work relatively longer hours, but then not receiving the same level of monetary compensation for her efforts. Yet, in the case where the wife's potential earning exceeds the husband's, the wife may be able to rationalize the unequal workload with the relatively higher income that she receives, which may act as an enough incentive to keep her participating in the labor market.

The behavioral effect reported in Bertrand et al.'s study, in which relative working hours within the household is not held constant in the regression analysis, is consistent with two models that have different welfare implications. In the gender identity norms model, which Bertrand et al. have used as the main explanation for women's behavior in the labor market, the welfare of both wife and husband drop as the wife's income exceeds the husband's. On the other hand, an increase in the relative work hours between spouses who both work whilst holding relative income and individual's own working hours constant should not have any significant effect on either partner's welfare so long as the distribution of relative income is not disrupted.

By contrast, in a model where (i) there is gender pay discrimination and (ii) the wife cares about gender wage fairness, the wife's welfare is expected to decrease as her working hours surpasses her husband's while, at the same time, relative income has remained the same. On the other hand, an increase in the share of wife's income, while holding relative working hours constant, is not predicted to have any negative welfare effect on either spouse so long as each spouse perceives the unexplained change in the relative income distribution as fair.

To the best of our knowledge, there has been little attempt to resolve these ambiguous theoretical predictions empirically. Using panel data from the British Household Panel Survey (BHPS), Booth and Van Ours (2008) report evidence that men's life satisfaction is not affected by how many hours they work. By contrast, part-time women report higher satisfaction with hours and job than full-time women, but their life satisfaction is unaffected by hours of work. Focusing more on married couples, the same authors also show using the Household, Income and Labor 
Dynamics in Australia (HILDA) that women's life satisfaction is higher if their partners work full-time. Male partners' life satisfaction, on the other hand, is unaffected by whether or not their female partners work part-time or full-time (Booth and Van Ours, 2009). What these findings suggest is that women prefer to work relatively fewer hours compared to their husbands, whereas men do not seem to be significantly affected either way. Yet, given that relative income is not controlled for in these studies, it is plausible that married women who work relatively fewer hours than their husbands are more satisfied simply because they are obeying the gender identity code: "a man should earn more than his wife".

\section{Implementing a test}

\subsection{Data}

The main data source used in this analysis is the American Time Use Survey (ATUS, 2012-2013). The ATUS is a nationally-representative data of American adults, which have been collected annually since 2003 on a sample of individuals randomly selected from a subset of households that have completed their eighth and final month of interviews for the Current Population Survey. It contains rich information on how respondents use their time during the day before the interview, as well as demographic information and job characteristics of the individuals. However, only one household member is asked to fill out the ATUS questionnaire on behalf of his/herself and other members in the family.

For two waves (2012 and 2013), the ATUS also asked respondents the following self-completed, cognitive well-being question: "Please imagine a ladder with steps numbered from zero at the bottom to ten at the top. The top of the ladder represents the best possible life for you and the bottom of the ladder represents the worst possible life for you. If the top step is 10 and the bottom is 0 , on which step of the ladder do you feel you personally stand at the present time?"

We focus our attention on all married couples who (i) respond to the life evaluation question, (ii) work and whose partner works, and (iii) age between 20 and 60 years old. This produces 4,195 individuals in total. Of those, 2,174 are women and 2,021 men. Approximately $48 \%$ of the male sample work longer than their wives, and $47 \%$ of the female sample work fewer hours than their husbands. Around $39 \%$ of 
individuals in the full sample work the same hours as their spouses, which leaves $11 \%$ of the couples whose wives work longer hours than their husbands.

In addition to the ATUS, we also utilize two nationally representative panel data sets from Germany and the UK to further assist our analysis. These are the German Socio-Economic Panel (SOEP, 1995-2008) and the British Household Panel Survey (BHPS, 1996-2008). Both the SOEP and the BHPS asked their respondents the following question: "How satisfied are you with your life overall?" The responses were based on a seven-point scale in the BHPS $(1=$ "very dissatisfied", $\ldots, 7=$ "very satisfied", and on an eleven-point scale in the SOEP $(0=$ "very dissatisfied", $\ldots, 10=$ "very satisfied"). This life satisfaction scale is similar in nature to the ATUS's life evaluation scale in that it elicits the respondent's cognitive well-being rather than their daily emotional experiences (Kahneman and Krueger, 2006). In the eyes of some researchers, particularly those from a psychology background, the single-item nature of our analysis is not necessarily ideal. However, we use large data sets, follow in an earlier tradition of such studies, and use comparisons across a number of data sets as a check on the reliability of results. Across all of our analysis, the well-being outcomes (life evaluation in the ATUS, and life satisfaction in the SOEP and the BHPS) are standardized to have a mean of zero and a standard deviation of 1 .

\subsection{Empirical strategy}

We consider, as our baseline specification, the following linear life evaluation regression equation:

$$
\begin{aligned}
L_{i}^{g}= & \alpha+\beta_{1} \times \text { WorkMoreThanPartner } \\
& { }_{3} \times X_{i}^{g}+\beta_{2} \times T+\varepsilon_{i}
\end{aligned}
$$

where $g$ indexes gender; $L E_{i}$ is individual $i$ 's standardized life evaluation (or life satisfaction); WorkMoreThanPartner ${ }_{i}^{g}$ is an indicator variable that has a value of 1 if the respondent's working hours is greater than his or her partner's working hours, and 0 otherwise; ShareWifeIncome ${ }_{i}^{g}$ is the share of wife's income within the

household, i.e., $\frac{\text { WifeIncome }}{\text { WifeIncome }+ \text { HusbandIncome }} ; X_{i}$ represents socio-economics and demographic characteristics, including age, age squared, log of own working hours 
per week, log of monthly income, self-assessed health, the number of children, education dummies, occupation dummies, and State of residence dummies; $T$ is time dummies; and $\varepsilon_{i}$ is the error term. The regression model is estimated using Ordinary Least Squares (OLS) with clustered standard errors at the State level. ${ }^{5}$

Given that WorksMoreThanPartner ${ }_{i}$ in Equation 1 is a choice variable and therefore likely to be endogenously determined, we later attempt to correct for the endogeneity problem by first instrumenting for WorkMoreThanPartner ${ }_{i}^{g}$ using lag differences between wages that had been averaged across the respondent's occupation and the partner's occupation in the 2010 Census, and lag differences between working hours that had been averaged across the respondent's occupation and the partner's occupation in the 2010 Census. The exclusion restriction here is that each partner's opportunity cost of not working longer hours than the other partner in 2010 should have a direct relationship with the partner's decision to work relatively longer hours than the other partner in 2012-2013, but should be uncorrelated with his or her life evaluation beyond its effect on the endogenous regressor.

In the latter analysis that allows for the use of panel data, we incorporate individual fixed effects into our life satisfaction regression equations in order to correct for the unobserved heterogeneity bias in our estimates. We also allow the robust standard errors to be clustered at the individual level in the SOEP and BHPS regressions.

\section{Results}

\subsection{Relative working hours and relative income within the household}

We begin with the assumption that, because of gender inequality in pay, the average share of wife's income within the household is less than $1 / 2$ among women who work the same number of hours as their husbands. Looking at the raw data, we find that the average shares of wife's income within the household are $0.35(S . D .=0.156)$ for women who work fewer hours than their husbands, $0.46(S . D .=0.131)$ for women

\footnotetext{
${ }^{5}$ Following the work by Ferrer-i-Carbonell and Frijters (2004), it should be stated here that it makes qualitatively little difference whether one assumes ordinality or cardinality in the subjective well-being data. For example, running an ordered probit model produces similar trade-offs between different variables in the regression as running a OLS regression.
} 
who work the same number of hours as their husbands, and 0.55 (S.D. $=0.159)$ for women who work more hours than their husbands. ${ }^{6}$ We can reject the null hypothesis of equal means for each pairing at the $1 \%$ level. The null hypothesis that each group's average share of wife's income within the household is statistically insignificantly different from $1 / 2$ is also rejected at the $1 \%$ level, thus implying that women who work the same number of hours as their husbands is still likely to earn less income as their husbands.

Unlike relative income, in which Bertrand et al. report evidence of a discontinuous decrease in the number of working women at the point where relative income is $1 / 2$, we do not find evidence of a similar magnitude of drop in the number of working women at the point where relative working hours within the household is $1 / 2$. Rather, the sharp drop in the number of observations of working women can be found at the ATUS where relative working hours is greater than $1 / 2$, i.e., in families where both partners work, there are 2,046 women who work fewer hours than their husbands and 1,635 women who work the same hours as their husbands, but there are only 514 women who work longer hours than their husbands. ${ }^{7}$ These aggregate numbers seem to suggest that women's decision of whether to participate in the labor market could have been driven by either their preferences for not wanting to violate the gender identity norm from earning more than their husbands, or by their dissatisfaction from having to work longer hours just to earn the same level of income as their husbands, or both.

In an attempt to separate the two effects, we ask the following question of our data: Are women who spend more time at the workplace compared to their husbands less satisfied with their lives overall? As a first pass to this question, Figure 1 divides men and women in the ATUS into four groups and provides a bar chart of the average life evaluation for each group. We can see that the most satisfied women are those whose working hours are either less or the same as their partners', whilst the most dissatisfied women are those who spend more than 1.5 times longer at the workplace than their husbands'. By contrast, the most satisfied men out of all four groups are those who spend more than 1.5 times longer at the workplace than their wives'.

\footnotetext{
${ }^{6}$ See descriptive statistics in Table $1 \mathrm{~A}$ in the Appendix.

${ }^{7}$ The raw correlation coefficient between relative income and relative working hours is 0.502 , which is far from perfect multicollinearity.
} 
Figure 1 is not to be seen as a formal test of the effect of relative working hours upon individual's overall life evaluation. This is because it does not control for other confounding influences, particularly the respondent's own working hours, the respondent's labor income, and especially the relative income within the household. Nevertheless, Figure 1 offers some initial indication that there may be a link between relative working hours and individual's overall life evaluation that is negative for women, but positive for men.

Table 1 reports our Equation 1's results for females and males in the ATUS data. The dependent variable is the standardized Cantril life ladder with a mean of 0 and a standard deviation of 1. Each regression equation controls for the respondent's own log of working hours per week, log of monthly labor income, the share of the wife's income, age, age-squared, self-assessed health, number of children, education dummies, occupational dummies, State dummies, and year dummies. Standard errors are clustered at the State level. Columns 1-4 present the results for women, and Columns 5-8 present the results for men.

In the first column of Table 1, our OLS regression indicates that women who work longer hours than their partners are approximately 0.2 standard deviations lower life evaluation compared to women who work fewer or the same number of hours as their husbands. This result is robust to controlling for the respondent's actual working hours, labor income, and relative income within the household. The coefficient changes slightly - although still remained negative and statistically significant - once we allowed for the reference group to change from "working less or the same hours as the partner" to "working the same hours as the partner" in Column 2. Replacing the dummy variable with a continuous "gap in working hours" variable $\left(\right.$ ownhours $_{i}$ - partnerhours $_{i}$ ) in Column 3 makes little difference to the results, producing an estimated coefficient of -0.219 with a standard error of 0.071 . Additionally, we find little evidence in Column 4 of Table 1 of a non-linear relationship between relative working hours and women's life evaluation scores.

In contrast, Columns 5-8 show that men who spend longer hours working do not report significantly lower life evaluation scores compared to men who either work fewer or the same number of hours as their wives. For example, the dummy variable 
“working longer hours than the partner" enters men's life evaluation regression with a coefficient of -0.039 and a standard error of $0.043 .^{8}$

Interestingly, the share of the wife's income - although entered each regression with the correct signs, i.e., negative for women and positive for men - is not statistically significantly different from zero in either female or male sub-sample analysis. We also find the estimated coefficient of $\log$ working hours to be statistically insignificantly determined for both men and women, which suggests that actual working hours may not matter significantly to either the wife's or the husband's overall well-being once we are able to hold constant the relative working hours within the household. Finally, log monthly labor income enters female's and male's life evaluation regressions in a positive manner, although the estimated income coefficients are statistically well-determined at the conventional levels only for females. ${ }^{9}$

Table 2 moves on to test whether Table 1's results vary significantly by the respondent's age and parenthood status. We do this by interacting the "working longer hours than the partner" dummy with either the "born before 1970" dummy or the "having at least one child" dummy in the life evaluation regression equation.

Looking across columns, we can see that women who work longer hours than their husbands and who were born after 1970 report, on average, 0.14 standard deviation lower life evaluation scores. By contrast, women who work longer hours than their husbands and who were born before 1970 do not report life evaluation scores that are statistically significantly different from other women of similar ages and who work either the same or fewer hours than their partners; the implied total effect of working longer hours than their husbands on the overall life satisfaction of women who were born before 1970 is $-0.140+0.175=-0.035(S . E .=0.079)$. This implies that younger women who work relatively longer hours compared to their husbands are the ones who significantly suffer from this arrangement within the household. On the other hand, we find in Column 3 that neither younger nor older

\footnotetext{
${ }^{8}$ We also show in Appendix 2A that the "U-index" (or the proportion of time spent in an unpleasant state) - see, e.g., Kahneman and Krueger (2006) - is significantly higher among women who work longer hours than their husbands. The same, however, does not apply to men.

${ }^{9}$ We also estimate different specifications with different set of control variables and report the results in Appendix 3A. Generally, we find the estimated coefficients on relative working hours to be consistently negative and statistically significant across different specifications in the female subsample, and statistically insignificantly different from zero across different specifications in the male sub-sample.
} 
men who work longer hours than their partners report life evaluation scores that are statistically significantly different from zero. One plausible explanations for this result is that, given a distribution of relative income between husbands and wives, younger generations of women care more than the older generations of women about getting a fair distribution of relative working hours. Another potential explanation for this is that older generations of women who were unhappy with the unfair work arrangement may have already separated from their husbands and are therefore not included in our sample. If this is the case, then this would explain why we do not observe a significant negative effect of relative working hours on the well-being of older women in our sample.

In Column 2 of Table 2, mothers with at least one child who work relatively longer hours than their husbands report, on average, around 0.12 standard deviation life evaluation scores lower than women who work fewer or the same hours as their husbands. The difference in the average life evaluation score is closer to zero between non-mothers who work relatively longer hours than their husbands and other women who work fewer or the same hours as their spouses, which suggests that the presence of children is one of the factors that amplifies the negative effect of the relative working hours on women's well-being in our data set. This might be because having a child implies that there will be more household chores that remains undone by the husband, which could potentially heighten the perceived feelings of unfairness that is harnessed by the wife who works longer hours than the husband. Finally, we find little evidence of a significant difference in life satisfaction between fathers and nonfathers who work relatively longer hours than their wives.

One concern is that relative working hours is endogenous to each partner's preferences towards working. One could imagine, for example, that women who are already unhappy at home may ceteris paribus choose to work longer hours than their husbands simply because they prefer working to being at home. In an attempt to alleviate such concern, we instrument relative income within the household using the lag differences between wages that had been averaged across the respondent's occupation and the partner's occupation in the 2010 Census, and the lag differences between working hours that had been averaged across the respondent's occupation and the partner's occupation in the 2010 Census as IVs. We then report the results for women in Table 3, and for men in Table 4. Note that we also hold the current level of 
relative income within the household, as well as other socio-demographic status, constant in all of these regression equations.

Looking across Tables 3 and 4, we can see that the estimated IV coefficients on the relative working hours dummy continue to be negative, sizeable, and statistically significant at conventional levels in the female sub-sample regressions, but not in the male sub-sample regressions. Comparing between OLS and IV estimators, the negative IV coefficient on working longer hours than the partner on females' life evaluation is around seven times the size of the OLS coefficient; a move from working less/the same hours to working longer hours than the husband reduces life evaluation scores by approximately 0.8 standard deviation. This result is consistent with the idea that women's decision to work longer hours than their husbands is endogenous to their pre-existing preferences towards working. For women whose opportunity cost of not working is high because of the market conditions, working longer hours than their husbands can potentially have a very large negative effect on their overall life evaluation scores. However, the same is not true for men who work relatively longer hours than their wives.

One important question is whether the IVs used in Tables 3 and 4 are consistent in producing sufficient variations in relative working hours. To address this issue, we ask four questions about the quality of the IVs. First, can we reject the null hypothesis of weak instruments? Looking at the first-stage regressions in both tables, we can see that both IVs are strong predictors of working longer hours than the partner for both genders; in equations with only one IV, the weak identification test produces large Cragg-Wald F-statistics $(F>45)$ that compare favorably to the statistics reported in Bound et al. (1995) and Stock and Yogo (2005). Second, can we be reasonably satisfied that the IVs have adequately identified the reduced-form equation? The Cragg-Donald F-statistics suggests that the reduced-form life evaluation regression is identified, given that the excluded IVs are sufficiently correlated with the endogenous regressor. Thirdly, can we satisfy the overidentifying assumption in the specifications where both IVs are included in the first-stage regression? The Sargan statistics reported in Column 3 of each table appear to support the conclusion of zero correlations between the outcome variable and the remaining instrument conditioning on the assumption that the other instrument satisfies the exclusion restrictions; Sargan statistics are statistically insignificantly different from 
zero with $p$-values of 0.893 for women and 0.953 for men. And finally, can we show that the IVs are not correlated with life evaluation beyond their correlations with the endogenous regression? This is evident in Columns 4 and 5 in which each IV is estimated to be statistically insignificantly different from zero when included in the second stage regression. Hence, we can be reasonably satisfied that the IVs are consistent in generating exogenous variations in the working longer hours than the partner dummy in the life evaluation regressions.

We are also interested in whether our findings on the effect of relative working hours on females' life evaluation will continue to hold in a panel fixed effects regression, as well as in different countries and time periods. Using 18 years of the German Socio-Economic Panel (SOEP, 1995-2012) and 12 years of the British Household Panel Survey (1996-2008) ${ }^{10}$, we estimate OLS and individual fixed effects (FE) life satisfaction regressions separately by gender and report the results in Table 5 . Consistent with the ATUS's findings, we find that, in both UK and Germany, women who work relatively longer hours than their husbands tend to report a statistically significantly lower level of life satisfaction than women who either work either fewer or the same hours to their husbands. The estimated effect of relative working hours is, however, neutral for German and British men. The introduction of individual FE does very little to change the size of the estimated coefficients, although including them has rendered the coefficient on working longer hours than the partner statistically insignificant at the $10 \%$ level in the BHPS.

In contrast to the findings obtained using the ATUS in Table 1, we find the OLS and IV coefficients on the share of the wife's income to be negatively and statistically significantly correlated with both women's and men's life satisfaction in Germany. This implies that, in Germany, both women and men tend to prefer that the wife earns relatively less than the husband, which is consistent with the traditional gender identity norm. As for the UK samples, we show that relative income is negatively correlated with women's life satisfaction, but positively correlated with men's life satisfaction in the OLS regressions. However, the estimated coefficients become statistically insignificantly different from zero with the inclusion of individual FE.

\footnotetext{
${ }^{10}$ Respondents were not asked a life satisfaction question in Wave 10 (2000) of the BHPS.
} 
In summary, we can conclude based on three nationally-representative data sets that women's overall life satisfaction is likely to be significantly lower when they work longer hours than their husbands. Men, on the other hand, do not report significantly lower life satisfaction when their relative working hours are higher than their wives. The results are robust to controlling for the respondent's own working hours, the respondent's own labor income, and the share of wife's income within the household.

\subsection{Potential mechanisms}

To understand better the mechanisms of the "relative working hours" effect and why it is only negative and statistically significant for females but not males, we plot in Figure 2 the average time use per activity in the ATUS separately by gender and by relative working hours. A Beckerian model implies that husbands whose wives work relatively longer hours than they do will step up and increase the number of hours they spend doing household chores. If this is the case, then the negative effect of working longer hours than the partner for women could be explained by their feelings of guilt from having violated another one of the traditional gender identity norms (e.g., "women should stay at home and take care of the family") rather than by their concerns for fairness. On the other hand, studies in sociology have found qualitative and quantitative evidence that men who earn less than their wives are likely to carry out more housework than other men, although women in these partnerships still do more housework than their husbands (e.g., Bittman et al., 2003; Tichenor, 2005; Lyonette and Crompton, 2015). What this implies is that women's concern for fairness may also extend towards how domestic work is arranged between them and their partners as well. If this is the case, then the negative effect of working longer hours than the partner for women could be explained by their feelings of dissatisfaction with their husbands being unhelpful at home rather than by their feelings of guilt for violating the gender identity norms.

We can see from Figure 2 that there is little difference in the time spend on household tasks between men who work fewer/the same hours as their partners and men who work longer hours than their partners. On average, men who work fewer/the same hours as their partners spend 103 minutes per day on household tasks, whereas 
men who work longer hours than their partners spend 94 minutes per day on household tasks. On the other hand, women who work longer than their husbands still spend, on average, around 137 minutes per day on household tasks, which is approximately 30 minutes longer than men who work fewer/the same hours as their wives and 38 minutes lower than women who work fewer/the same hours as their husbands.

Women who work longer than their husbands spend around 457 minutes working, which is 84 minutes longer than women who work fewer/the same hours as their husbands. That is a large difference, considering that men who work longer than their wives spend around 32 minutes longer at work than men who work fewer/the same hours as their wives. Interestingly, there is virtually no difference in the average leisure time between men who work fewer/the same hours as their wives (174.9 minutes per day) and men who work longer hours than their wives (171.5 minutes per day). By contrast, women who work longer hours than their husbands spend, on average, 135.1 minutes on leisure activities, which is around 13 minutes less than women who work fewer/the same hours as their husbands. These aggregate numbers provide some first evidence that men do not generally compensate their wives for working relative longer hours than they do by taking on more household tasks, thus rejecting the Beckerian hypothesis.

Table 6 provides OLS and IV estimates on the effect of working longer hours than the partner on time use across different activities. Consistent with Figure 2, we find little evidence from OLS and IV regressions to suggest that men increase time spend on household tasks significantly as a result from working relatively fewer hours than their wives. However, men are likely to reduce the time spend on household chores as a result of having to work longer hours than their wives; the estimated IV coefficient on working longer than the wife in the log household tasks equation is negative and statistically significant at the 5\% level. We also do not find strong evidence to suggest that, holding other things constant, women who work longer hours than their husbands spend significantly less time doing household chores compared to women who work fewer/the same hours as their husbands.

Table 7 tests whether the negative "relative working hours" effect on women's life evaluation can be explained by the evidence that men do not compensate their wives for working longer hours than they do by engaging in more household tasks. 
We do this by re-estimating Table 1's life evaluation regression with an interaction term between "working longer hours than the partner" and "log of household tasks in minutes" as an additional regressor in the equation.

Looking across the columns, we can see that life evaluation is significantly lower only among women who work relatively longer hours than their husbands and who also spend a significant amount of time doing household chores. While the main effect of working longer hours than the husband is statistically insignificant, its interaction effect with log of time spent on household tasks per day is negative, sizeable, and statistically well-determined. This finding sits awkwardly with Bertrand et al.'s assumption that women choose to do relatively more household because she feels guilty for having violated the gender norm and wants to feel better about herself. Nevertheless, it seems to be more consistent with the idea that women who work longer hours than their husbands feel unfairly treated for having to come home and work the "second shift" as well (Hochschild and Machung, 1989).

Table 8, as a further check on the fairness hypothesis, uses the British panel data to check whether individual's attitudes towards traditional gender norm are significantly moderated by the relative working hours variable. We find women to be more egalitarian in their attitudes compared to men in general. More specifically, women are less likely than men to agree that family suffers if mother works full-time, that husband should earn and wife should stay at home, and that children need father as much as mother. Also, women are more likely than men to agree that women and family are happier if she works, that husband and wife should both contribute, and that full-time job makes women independent.

Men whose wives work longer hours than they do also hold less traditional views on gender roles compared to men whose wives work fewer/the same hours, on average. This is evidently clear from looking at some of the estimated main effects of "wife is working longer hours". For example, the main effect of "wife is working longer hours" is negative and statistically well-defined in Column 1, which implies that men whose wives work longer hours are less likely to agree that family suffers if mother works full-time.

However, as can be seen from the total implied effects, women who work longer hours than their husbands are consistently the most egalitarian of all groups. For example, in the "full-time job makes women independent" regression, women 
who work longer hours than their husbands score 0.57 standard deviation higher in terms of agreement with the statement than men who work longer hours than their wives. The next most egalitarian group consists of women who work fewer/the same hours as their husbands (0.38 standard deviation higher) and then men who work fewer/the same hours as their wives (0.20 standard deviation higher).

Interestingly, the same can also be said about the estimated effects of relative income on each partner's attitudes towards traditional gender roles. Holding relative working hours constant, partners in a couple where the wife earns more than the husband tend to hold relatively more egalitarian views compared to partners in a couple where the wife earns less or the same as the husbands. Table 8's results provide evidence that is inconsistent with the idea that women who work and/or earn more than their husbands feel guilty for having violated the gender identity norm.

\subsection{Implications on future behaviors}

Using the German and British longitudinal data, Table 9 estimates a probit model in of individual's propensity to quit and leave the labor force altogether in year $t+1 .^{11}$ What we find is that, holding the share of wife's income constant, women who work relatively longer hours than their husbands are statistically significantly more likely to quit their current job in year $t+1$. They are also more likely to leave the labor force altogether in year $t+1$. The estimates are robust in both the German and the British panels. On the other hand, there is only a weak evidence in the SOEP that men who work relative longer hours than wives are more likely to quit their current job in year $t$ +1 . In addition to this, there is little evidence that an increase in the share of wife's income increases the likelihood of women leaving the labor force in year $t+1$ when relative working hours is being held constant in the regression, which is more consistent with the concern for fairness hypothesis than the gender identity hypothesis.

Applying both linear probability and probit models, Table 10 examines the roles of relative working hours on couple's propensity to separate/divorce in year $t+$ 1. With one observation per family per year, we find the probability that partners in a couple will either separate or divorce in year $t+1$ to be statistically significantly higher if the wife works relatively longer than the husband. The estimated coefficients

\footnotetext{
${ }^{11}$ Qualitatively similar results are obtained using a linear probability model.
} 
are robust to controlling for the share of wife's income within the household, which also happens to be positive and statistically significant at conventional levels in both SOEP and BHPS.

The estimated coefficients of "wife working longer hours than the husband" in the separated/divorce in year $t+1$ regression are also quantitatively important as well as statistically significant. For example, an increase in the absolute family income of around $1 \%$ is required to just offset the negative effect that relative working hours has on the couple's probability of marital dissolution within the next 12 months.

In summary, the evidence on future job quits and marital dissolution seems to be consistent with the idea that women may feel unjustified that they have to spend significantly longer hours at the workplace in order for a chance to earn the same level of income as their husbands. And when they do, their husbands do not compensate them enough by increasing the time that they spend doing household tasks, which can increase women's dissatisfaction at home and raises the probability of separation/divorce in the future.

\section{Conclusions}

Bertrand et al. (2015)'s latest research on gender identity and relative income offers an important and timely explanation for why we continue to observe significant gender gaps in both labor market participation and in earnings, despite substantial labor market gains for women over the last fifty years. According to their findings, women tend to avoid selecting themselves into a job or a work arrangement that enables them to earn more than their husbands. This is simply because they do not want to feel guilty for violating the traditional gender identity prescription: "a man should earn more than his wife".

The current study argues that there may be an alternative explanation to Bertrand et al.'s findings, which is that women may care more about what is considered as fair than whether or not their actions are deeming to be violating the traditional gender identity norm. Using three nationally representative data sets, we show that life evaluation (or life satisfaction) is significantly lower among women who work relatively longer hours than their husbands, holding - among other things the relative income within the household constant. This result seems to apply only to 
women as men who work longer hours than their wives do not report a life evaluation score that is, on average, statistically different from men who work fewer/the same hours as their wives. On the other hand, we do not find evidence, at least in the American Time Use Survey, to suggest that an increase in the share of wife's income depresses the life evaluation of either partner in the household. Our further analysis also reveals that men who work fewer/the same hours as their wives do not seem to alter their time spent on household tasks in a significant way, which may contribute further to women's dissatisfaction from having to work longer hours than their husbands.

While we cannot completely rule out that women's beliefs in the traditional gender identity, "a man should earn more than his wife", do not play a part in determining their decision to participate in the labor market, our results do suggest that the complete picture is much more complex than what has been painted in Bertrand et al.'s study. It is possible that women's concerns for fairness and the profound beliefs among men on the behavioral prescription, "a woman should do more housework than her husband", may in fact play a more prominent role in determining both women's and men's behaviors in today's marriage and labor markets. In other words, it may not be so much up to women who need to alter their perspectives towards women working, but rather men who do. 


\section{References}

Akerlof, George A. and Rachel E. Kranton. 2000. Economics and identity. Quarterly Journal of Economics, 115(3), 715-753.

Akerlof, George A. and Rachel E. Kranton. 2010. Identity Economics: How Our Identities Affect Our Work, Wages, and Well-being. Princeton: Princeton University Press.

Altonji, Joseph G. and Rebecca M. Blank. 1999. Race and gender in the labor market. Handbook of labor economics, 3, pp.3143-3259.

Arpino, Bruno, Gøsta Esping-Andersen, and Léa Pessin. 2015. How do changes in gender role attitudes towards female employment influence fertility? A macro-level analysis. European Sociological Review, 31(3), pp.370-382.

Becker, Gary S., 1973. A theory of marriage: Part I. Journal of Political Economy, 81(4), 813-846.

Becker, Gary S., 1974. A Theory of Marriage: Part II. Journal of Political Economy, 82(2), S11-S26.

Bertrand, Marianne, Emir Kamenica, and Jessica Pan. 2015. Gender identity and relative income within households. Quarterly Journal of Economics, 130(2), 571-614. Bittman, Michael, Paula England, Liana Sayer, L., Nancy Folbre, and George Matheson. 2003. When Does Gender Trump Money? Bargaining and Time in Household Work1. American Journal of sociology, 109(1), pp.186-214.

Blau, Francine D. and Lawrence M. Kahn. 1992. The gender earnings gap: learning from international comparisons. American Economic Review, 82(2), pp.533-538. Blau, Francine D. and Lawrence M. Kahn. 2006. The US gender pay gap in the 1990s: Slowing convergence. Industrial \& Labor Relations Review, 60(1), pp.45-66. Booth, Alison L. and Jan C. Van Ours. 2008. Job satisfaction and family happiness: the part-time work puzzle. Economic Journal, 118(526), pp. F77-F99.

Booth, Alison L. and Jan C. Van Ours. 2009. Hours of Work and Gender Identity: Does Part-Time Work Make the Family Happier? Economica, 76(301), pp.176-196. Bound, John, David A. Jaeger, and Regina M. Baker. 1995. Problems with instrumental variables estimation when the correlation between the instruments and the endogenous explanatory variable is weak." Journal of the American Statistical Association 90(430), 443-450. 
Cotter, David, Joan M. Hermsen, and Reeve Vanneman. 2011. The End of the Gender Revolution? Gender Role Attitudes from 1977 to 20081." American Journal of Sociology 117(1), 259-289.

Donnelly, Kristin, Jean M. Twenge, Malissa A. Clark, Samia K. Shaikh, Angela Beiler-May, and Nathan T. Carter. Forthcoming. Attitudes toward women's work and family roles in the United States, 1976-2013. Psychology of Women Quarterly. Farré, Lídia, and Francis Vella. 2013. The intergenerational transmission of gender role attitudes and its implications for female labor force participation." Economica 80(318), 219-247.

Ferrer-i-Carbonell, Ada, and Paul Frijters, P. 2004. How important is methodology for the estimates of the determinants of happiness? Economic Journal, 114(497), 641-659. Fortin, Nicole M., 2005. Gender role attitudes and the labour-market outcomes of women across OECD countries. Oxford review of Economic Policy, 21(3), pp.416438.

Hochschild, Arlie and Anne Machung. 1989. The Second Shift. New York: Viking. Jarrell, S.B. and Stanley, T.D., 2004. Declining bias and gender wage discrimination? A meta-regression analysis. Journal of Human Resources, 39(3), pp.828-838.

Kahneman, Daniel, and Alan B. Krueger. 2006. Developments in the measurement of subjective well-being. Journal of Economic Perspectives 20(1), 3-24.

Lyonette, Clare, and Rosemary Crompton. 2015. Sharing the load? Partners' relative earnings and the division of domestic labour. Work, Employment \& Society, 29(1), $23-40$.

Stock, James H., and Motohiro Yogo. 2005. Testing for Weak Instruments in Linear IV Regression. In Andrews, Donald W.K. and Stock, James H. (eds), Identification and Inference for Econometric Models: Essays in Honor of Thomas Rothenberg, 80108. Cambridge University Press.

Tichenor, Veronica J. 2005. Earning More and Getting Less: Why Successful Wives Can't Buy Equality. New Brunswick, NJ and London: Rutgers University Press. 
Figure 1: Raw data correlations between life evaluation and relative work hours by gender, American Time Use Survey, 2012-2013

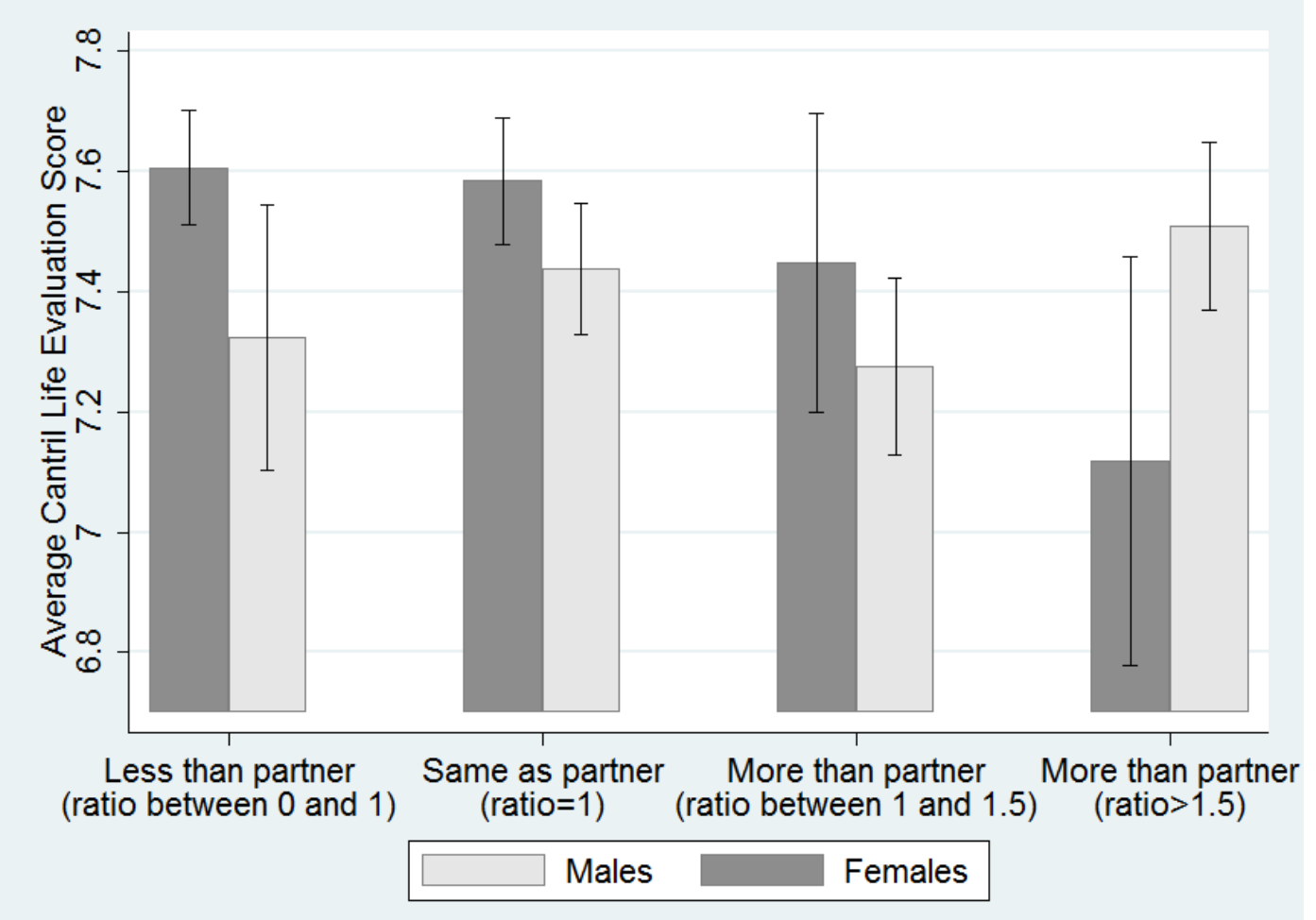

Note: Unstandardized life evaluation score is measured on an 11-point scale that ranges from 0 (the worst possible life) to 10 (the best possible life). The ratio of work hours between spouses = individual's own usual work hours $\left(H_{i}\right)$ /spouse's usual work hours $\left(H_{s}\right) .90 \%$ standard-error bars are reported (1 S.E. above, 1 S.E. below). 
Table 1: Cantril life ladder and relative working hours among couples (OLS), American Time Use Survey, $2012-2013$

\begin{tabular}{|c|c|c|c|c|c|c|c|c|}
\hline & \multicolumn{4}{|c|}{ Females } & \multicolumn{4}{|c|}{ Males } \\
\hline & (1) & $(2)$ & (3) & (4) & (5) & $(6)$ & $(7)$ & (8) \\
\hline $\begin{array}{l}\text { Working longer hours than the } \\
\text { partner (dummy: } H_{i}-H_{j}>0 \text { ) }\end{array}$ & $\begin{array}{l}-0.181^{* * *} \\
(0.065)\end{array}$ & $\begin{array}{l}-0.167^{* *} \\
(0.073)\end{array}$ & & & $\begin{array}{l}-0.039 \\
(0.043)\end{array}$ & $\begin{array}{l}-0.047 \\
(0.045)\end{array}$ & & \\
\hline $\begin{array}{l}\text { Working fewer hours than the partner } \\
\text { (dummy: } H_{i}-H_{j}<0 \text { ) }\end{array}$ & & $\begin{array}{c}0.035 \\
(0.065)\end{array}$ & & & & $\begin{array}{l}-0.048 \\
(0.068)\end{array}$ & & \\
\hline Gap in working hours $\left(H_{i}-H_{j}\right)$ & & & $\begin{array}{l}-0.219^{* * *} \\
(0.071)\end{array}$ & $\begin{array}{l}-0.228^{* * *} \\
(0.074)\end{array}$ & & & $\begin{array}{c}0.050 \\
(0.051)\end{array}$ & $\begin{array}{c}0.046 \\
(0.076)\end{array}$ \\
\hline Gap in working hours-squared & & & & $\begin{array}{c}0.021 \\
(0.046)\end{array}$ & & & & $\begin{array}{r}0.002 \\
(0.023)\end{array}$ \\
\hline Log (Working hours/week) & $\begin{array}{c}0.000 \\
(0.073)\end{array}$ & $\begin{array}{c}0.013 \\
(0.075)\end{array}$ & $\begin{array}{c}0.185 \\
(0.115)\end{array}$ & $\begin{array}{c}0.236 \\
(0.153)\end{array}$ & $\begin{array}{c}0.052 \\
(0.091)\end{array}$ & $\begin{array}{c}0.035 \\
(0.089)\end{array}$ & $\begin{array}{l}-0.022 \\
(0.111)\end{array}$ & $\begin{array}{l}-0.017 \\
(0.144)\end{array}$ \\
\hline Log (Monthly Income) & $\begin{array}{l}0.062^{*} \\
(0.035)\end{array}$ & $\begin{array}{l}0.064^{*} \\
(0.035)\end{array}$ & $\begin{array}{l}0.058^{*} \\
(0.031)\end{array}$ & $\begin{array}{l}0.053^{*} \\
(0.030)\end{array}$ & $\begin{array}{c}0.045 \\
(0.042)\end{array}$ & $\begin{array}{c}0.045 \\
(0.042)\end{array}$ & $\begin{array}{c}0.055 \\
(0.044)\end{array}$ & $\begin{array}{c}0.055 \\
(0.044)\end{array}$ \\
\hline Share of the wife's income & $\begin{array}{l}-0.088 \\
(0.092)\end{array}$ & $\begin{array}{l}-0.086 \\
(0.094)\end{array}$ & $\begin{array}{l}-0.085 \\
(0.097)\end{array}$ & $\begin{array}{l}-0.090 \\
(0.097)\end{array}$ & $\begin{array}{c}0.027 \\
(0.163)\end{array}$ & $\begin{array}{c}0.030 \\
(0.164)\end{array}$ & $\begin{array}{c}0.119 \\
(0.195)\end{array}$ & $\begin{array}{c}0.118 \\
(0.201)\end{array}$ \\
\hline $\begin{array}{l} \\
R^{2}\end{array}$ & $\begin{array}{l}2174 \\
0.138\end{array}$ & $\begin{array}{l}2174 \\
0.138\end{array}$ & $\begin{array}{l}2174 \\
0.138\end{array}$ & $\begin{array}{l}2174 \\
0.138\end{array}$ & $\begin{array}{l}2021 \\
0.122\end{array}$ & $\begin{array}{l}2021 \\
0.122\end{array}$ & $\begin{array}{l}2021 \\
0.122\end{array}$ & $\begin{array}{l}2021 \\
0.122\end{array}$ \\
\hline
\end{tabular}

Note: ${ }^{*} p<0.1,{ }^{* *} p<0.05,{ }^{* * *} p<0.01$.

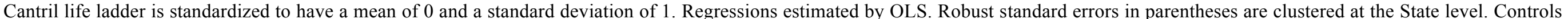
include the age and the age squared, self-assessed health, the number of children, education dummies, occupation dummies, State dummies and year dummies. 
Table 2: Interaction effects

\begin{tabular}{|c|c|c|c|c|}
\hline & \multicolumn{2}{|c|}{ Females } & \multicolumn{2}{|c|}{ Males } \\
\hline & (1) & (2) & (3) & (4) \\
\hline $\begin{array}{l}\text { Working longer hours than the partner } \\
\text { (dummy) }\end{array}$ & $\begin{array}{l}-0.140^{* *} \\
(0.061)\end{array}$ & $\begin{array}{c}0.058 \\
(0.093)\end{array}$ & $\begin{array}{l}-0.022 \\
(0.048)\end{array}$ & $\begin{array}{c}0.025 \\
(0.132)\end{array}$ \\
\hline $\begin{array}{l}\text { Working longer hours than the partner } \\
\text { (dummy) } \times \text { Born before } 1970\end{array}$ & $\begin{array}{l}0.175^{* *} \\
(0.070)\end{array}$ & & $\begin{array}{l}-0.037 \\
(0.065)\end{array}$ & \\
\hline $\begin{array}{l}\text { Working longer hours than the partner } \\
\text { (dummy) } \times \text { Having at least one child }\end{array}$ & & $\begin{array}{l}-0.174^{*} \\
(0.093)\end{array}$ & & $\begin{array}{c}0.012 \\
(0.160)\end{array}$ \\
\hline Share of the wife income & $\begin{array}{l}-0.111 \\
(0.095)\end{array}$ & $\begin{array}{l}-0.120 \\
(0.096)\end{array}$ & $\begin{array}{c}0.025 \\
(0.163)\end{array}$ & $\begin{array}{c}0.067 \\
(0.160) \\
\end{array}$ \\
\hline $\begin{array}{l}N \\
R^{2}\end{array}$ & $\begin{array}{l}2174 \\
0.138\end{array}$ & $\begin{array}{l}2174 \\
0.137 \\
\end{array}$ & $\begin{array}{l}2021 \\
0.122\end{array}$ & $\begin{array}{c}2021 \\
0.122\end{array}$ \\
\hline $\begin{array}{l}\text { Implied total effect for: } \\
\text { Workers working longer hours than the } \\
\text { partner born before } 1970 \\
\text { Workers working longer hours than the } \\
\text { partner born after } 1970 \\
\text { Workers working longer hours than the } \\
\text { partner with at least one child } \\
\text { Workers working longer hours than the } \\
\text { partner with no child }\end{array}$ & $\begin{array}{c}-0.035 \\
(0.079) \\
-0.140^{* *} \\
(0.061)\end{array}$ & $\begin{array}{c}-0.125^{* *} \\
(0.060) \\
0.058 \\
(0.093) \\
\end{array}$ & $\begin{array}{c}-0.059 \\
(0.060) \\
-0.022 \\
(0.048)\end{array}$ & $\begin{array}{c}0.047 \\
(0.080) \\
0.025 \\
(0.132)\end{array}$ \\
\hline
\end{tabular}

Note: ${ }^{*} p<0.1,{ }^{* *} p<0.05,{ }^{* * *} p<0.01$. Regressions estimated by OLS. Standard errors in parentheses are clustered at the State level. Controls include the age and the age squared, the actual number of working hours per week, the log of the weekly labour income, occupational dummies, self-assessed health, the number of children, the share of wife's income, education dummies, State dummies and year dummies. 
Table 3: Cantril life ladder and relative working hours among couples (IV/2SLS) - Females sample

\begin{tabular}{|c|c|c|c|c|c|}
\hline \multicolumn{6}{|c|}{ Panel A: IV estimates in Cantril life ladder regression equation } \\
\hline & (1) & $(2)$ & (3) & (4) & (5) \\
\hline Working longer hours than the & $-0.773^{*}$ & $-0.743^{* *}$ & $-0.774^{* *}$ & $-0.736^{*}$ & -0.829 \\
\hline partner (measured in 2012-13) & $(0.439)$ & $(0.377)$ & $(0.304)$ & $(0.430)$ & $(0.515)$ \\
\hline $\begin{array}{l}\text { Average wage by occupation } \\
\text { minus average partner's wage } \\
\text { (measured in 2010) }\end{array}$ & & & & $\begin{array}{l}-0.006 \\
(0.042)\end{array}$ & \\
\hline $\begin{array}{l}\text { Average working hours by } \\
\text { occupation minus average } \\
\text { partner's working hours } \\
\text { (measured in 2010) }\end{array}$ & & & & & $\begin{array}{c}0.006 \\
(0.049)\end{array}$ \\
\hline \multicolumn{6}{|c|}{ Panel B: First-stage regression with working longer hours than the partner (dummy) as the dependent variable } \\
\hline $\begin{array}{l}\text { Average wage by occupation } \\
\text { minus average partner's wage } \\
\text { (measured in 2010) }\end{array}$ & $\begin{array}{l}0.070^{* * *} \\
(0.010)\end{array}$ & & $\begin{array}{l}0.060^{* * *} \\
(0.010)\end{array}$ & & $\begin{array}{l}0.060^{* * *} \\
(0.010)\end{array}$ \\
\hline $\begin{array}{l}\text { Average working hours by } \\
\text { occupation minus average } \\
\text { partner's working hours } \\
\text { (measured in 2010) }\end{array}$ & & $\begin{array}{l}0.077^{* * *} \\
(0.013)\end{array}$ & $\begin{array}{l}0.071^{* * *} \\
(0.010)\end{array}$ & $\begin{array}{l}0.071^{* * *} \\
(0.010)\end{array}$ & \\
\hline$N$ & 2137 & 2137 & 2137 & 2137 & 2137 \\
\hline Partial $R^{2}$ & 0.022 & 0.030 & 0.046 & 0.026 & 0.017 \\
\hline Under identification test & 0.000 & 0.000 & 0.000 & 0.000 & 0.000 \\
\hline Cragg-Donald F stat. & 46.919 & 63.728 & 49.939 & 54.283 & 35.093 \\
\hline Sargan stat. & $\mathrm{N} / \mathrm{A}$ & $\mathrm{N} / \mathrm{A}$ & 0.893 & $\mathrm{~N} / \mathrm{A}$ & $\mathrm{N} / \mathrm{A}$ \\
\hline
\end{tabular}

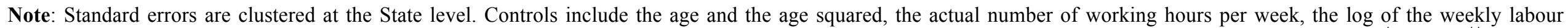

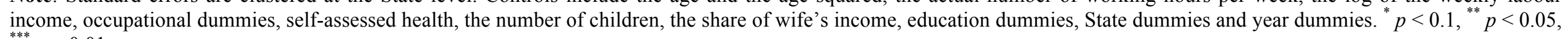
${ }^{* *} p<0.01$ 
Table 4: Cantril life ladder and relative working hours among couples (IV/2SLS) - Males sample

\begin{tabular}{|c|c|c|c|c|c|}
\hline \multicolumn{6}{|c|}{ Panel A: IV estimates in Cantril life ladder regression equation } \\
\hline & (1) & (2) & (3) & (4) & (5) \\
\hline $\begin{array}{l}\text { Working longer hours than the } \\
\text { partner (measured in } 2012-13 \text { ) }\end{array}$ & $\begin{array}{l}-0.072 \\
(0.253)\end{array}$ & $\begin{array}{l}-0.095 \\
(0.317)\end{array}$ & $\begin{array}{l}-0.081 \\
(0.210)\end{array}$ & $\begin{array}{l}-0.070 \\
(0.280)\end{array}$ & $\begin{array}{l}-0.099 \\
(0.375)\end{array}$ \\
\hline $\begin{array}{l}\text { Average wage by occupation } \\
\text { minus average partner's wage } \\
\text { (measured in } 2010 \text { ) }\end{array}$ & & & & $\begin{array}{l}-0.003 \\
(0.048)\end{array}$ & \\
\hline $\begin{array}{l}\text { Average working hours by } \\
\text { occupation minus average } \\
\text { partner's working hours } \\
\text { (measured in 2010) }\end{array}$ & & & & & $\begin{array}{c}0.002 \\
(0.041)\end{array}$ \\
\hline \multicolumn{6}{|c|}{ Panel B: First-stage regression with working longer hours than the partner (dummy) as the dependent variable } \\
\hline $\begin{array}{l}\text { Average wage by occupation } \\
\text { minus average partner's wage } \\
\text { (measured in } 2010 \text { ) }\end{array}$ & $\begin{array}{l}0.090^{* * *} \\
(0.010)\end{array}$ & & $\begin{array}{l}0.096^{* * *} \\
(0.016)\end{array}$ & & $\begin{array}{l}0.096^{* * *} \\
(0.016)\end{array}$ \\
\hline $\begin{array}{l}\text { Average working hours by } \\
\text { occupation minus average } \\
\text { partner's working hours } \\
\text { (measured in 2010) }\end{array}$ & & $\begin{array}{l}0.113^{* * *} \\
(0.016)\end{array}$ & $\begin{array}{l}0.082^{* * *} \\
(0.010)\end{array}$ & $\begin{array}{l}0.084^{* * *} \\
(0.010)\end{array}$ & \\
\hline$N$ & 1992 & 1992 & 1992 & 1992 & 1992 \\
\hline Partial $R^{2}$ & 0.021 & 0.039 & 0.057 & 0.033 & 0.019 \\
\hline Under identification test & 0.000 & 0.000 & 0.000 & 0.000 & 0.000 \\
\hline Cragg-Donald F stat. & 77.746 & 49.058 & 57.647 & 64.602 & 36.119 \\
\hline Sargan stat. & N/A & $\mathrm{N} / \mathrm{A}$ & 0.953 & N/A & N/A \\
\hline
\end{tabular}

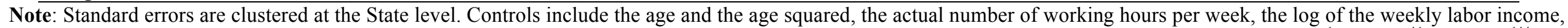

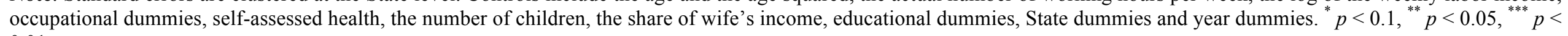
0.01 
Table 5: Replication of the baseline results using SOEP (1995-2012) and BHPS (1996-2008), OLS and FE regressions

\begin{tabular}{|c|c|c|c|c|c|c|c|c|}
\hline & \multicolumn{4}{|c|}{ SOEP } & \multicolumn{4}{|c|}{ BHPS } \\
\hline & \multicolumn{2}{|c|}{ Females } & \multicolumn{2}{|c|}{ Males } & \multicolumn{2}{|c|}{ Females } & \multicolumn{2}{|c|}{ Males } \\
\hline Working longer & $-0.036^{* *}$ & $-0.038^{* * *}$ & -0.005 & 0.001 & $-0.063^{* *}$ & -0.041 & -0.028 & 0.005 \\
\hline $\begin{array}{l}\text { hours than the } \\
\text { partner }\end{array}$ & $(0.018)$ & $(0.014)$ & $(0.017)$ & $(0.013)$ & $(0.029)$ & $(0.029)$ & $(0.021)$ & $(0.022)$ \\
\hline Log (Working & $-0.162^{* * *}$ & -0.016 & $-0.172^{* * *}$ & -0.001 & $-0.125^{* * *}$ & -0.035 & -0.081 & $-0.105^{*}$ \\
\hline hours/week) & $(0.018)$ & $(0.016)$ & $(0.032)$ & $(0.028)$ & $(0.035)$ & $(0.035)$ & $(0.052)$ & $(0.055)$ \\
\hline Log (Monthly & $0.210^{* * * *}$ & $0.061^{* * * *}$ & $0.256^{* * * *}$ & $0.110^{* * * *}$ & $0.077^{* * * *}$ & 0.006 & $0.111^{* * *}$ & $0.076^{* * *}$ \\
\hline Income) & $(0.014)$ & $(0.012)$ & $(0.015)$ & $(0.014)$ & $(0.025)$ & $(0.027)$ & $(0.025)$ & $(0.031)$ \\
\hline Share of the & $-0.203^{* * *}$ & $-0.589^{* * * *}$ & $-0.117^{* * *}$ & $-0.365^{* * *}$ & $-0.410^{* * *}$ & -0.089 & $0.440^{* * *}$ & 0.029 \\
\hline wife income & $(0.019)$ & $(0.141)$ & $(0.016)$ & $(0.137)$ & $(0.137)$ & $(0.116)$ & $(0.158)$ & $(0.167)$ \\
\hline$N$ & 46864 & 46864 & 45475 & 45475 & 19982 & 19982 & 18404 & 18404 \\
\hline Individual FE & No & Yes & No & Yes & No & Yes & No & Yes \\
\hline
\end{tabular}

Note: Regressions estimated by OLS. Standard errors in parentheses are clustered at the individual level. Controls include the age and the age squared, the log of the actual number of working hours per week, the log of the weekly labor income, occupational dummies, self-assessed health, the number of children, the share of wife's income, education dummies, regional dummies and year fixed effects. ${ }^{*} p$ $<0.1,{ }^{* *} p<0.05,{ }^{* * *} p<0.01$ 
Figure 2: Time use, American Time Use Survey, 2012-2013
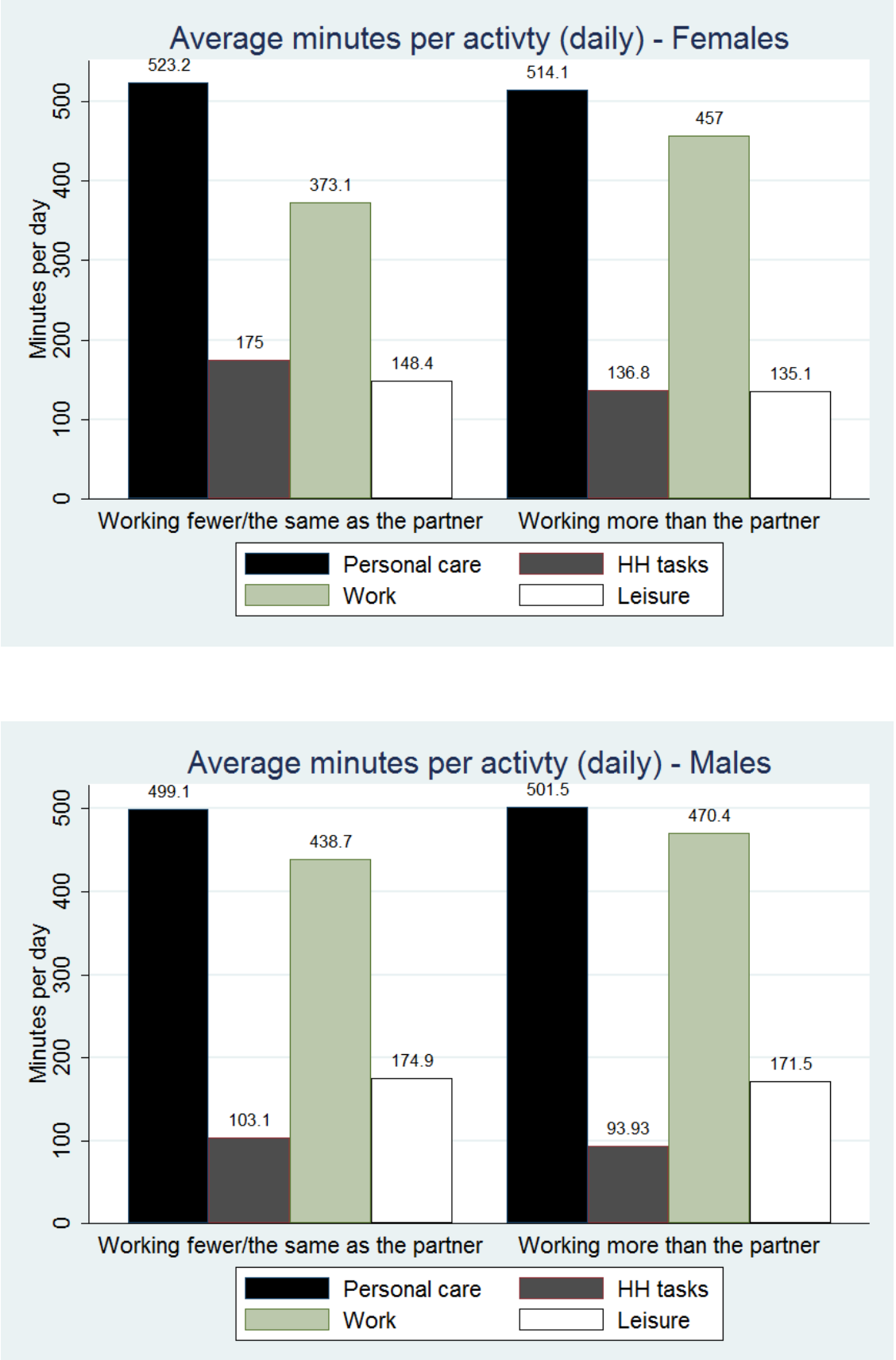
Table 6: Activity per day and relative working hours (OLS), American Time Use Survey, 2012-2013

\begin{tabular}{|c|c|c|c|c|c|c|}
\hline & \multicolumn{2}{|c|}{ Log (personal care) } & \multicolumn{2}{|c|}{ Log (HH tasks) } & \multicolumn{2}{|c|}{ Log(leisure) } \\
\hline & Females & Males & Females & Males & Females & Males \\
\hline \multicolumn{7}{|l|}{ Panel A: Coefficients estimated using OLS } \\
\hline Working longer hours than the partner & -0.024 & -0.005 & -0.166 & -0.028 & -0.006 & -0.048 \\
\hline (dummy) & $(0.015)$ & $(0.012)$ & $(0.111)$ & $(0.086)$ & $(0.109)$ & $(0.072)$ \\
\hline \multirow[t]{2}{*}{ Working hours/week (log) } & -0.003 & -0.046 & $-0.284^{* * *}$ & -0.228 & $-0.219^{* * *}$ & $-0.403^{* *}$ \\
\hline & $(0.010)$ & $(0.033)$ & $(0.067)$ & $(0.188)$ & $(0.059)$ & $(0.116)$ \\
\hline \multirow[t]{2}{*}{ Share of wife income } & -0.026 & -0.002 & 0.078 & 0.381 & -0.090 & -0.074 \\
\hline & $(0.018)$ & $(0.030)$ & $(0.142)$ & $(0.256)$ & $(0.112)$ & $(0.140)$ \\
\hline$N$ & 2174 & 2021 & 2174 & 2021 & 2174 & 2021 \\
\hline $\mathrm{R}^{2}$ & 0.100 & 0.070 & 0.023 & 0.037 & 0.041 & 0.056 \\
\hline \multicolumn{7}{|c|}{ Panel B: Coefficients estimated using IV/2SLS } \\
\hline Working longer hours than the partner & -0.064 & -0.057 & -0.572 & $-1.403^{* *}$ & 0.898 & 0.557 \\
\hline (dummy) & $(0.099)$ & $(0.089)$ & $(0.696)$ & $(0.656)$ & $(0.715)$ & $(0.465)$ \\
\hline \multirow[t]{2}{*}{ Working hours/week (log) } & -0.017 & 0.004 & -0.077 & 0.545 & $-0.335^{* * * *}$ & $-0695^{* *}$ \\
\hline & $(0.020)$ & $(0.063)$ & $(0.143)$ & $(0.498)$ & $(0.147)$ & $(0.353)$ \\
\hline \multirow[t]{2}{*}{ Share of wife income } & -0.031 & -0.042 & 0.272 & -0.191 & -0.269 & 0.242 \\
\hline & $(0.028)$ & $(0.079)$ & $(0.199)$ & $(0.618)$ & $(0.205)$ & $(0.437)$ \\
\hline$N$ & 2137 & 1992 & 2137 & 1992 & 2137 & 1992 \\
\hline Partial $R^{2}$ & 0.021 & 0.025 & 0.021 & 0.025 & 0.021 & 0.025 \\
\hline Under identification test & 0.000 & 0.000 & 0.000 & 0.000 & 0.000 & 0.000 \\
\hline Cragg-Donald F stat. & 43.676 & 49.161 & 43.676 & 49.161 & 43.676 & 49.161 \\
\hline
\end{tabular}

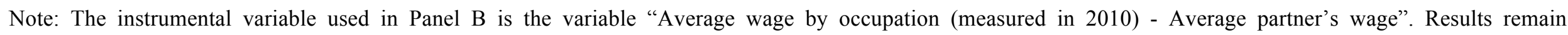

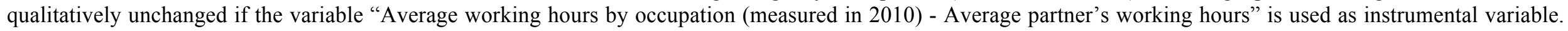

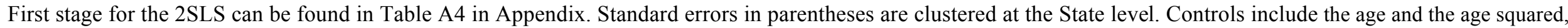

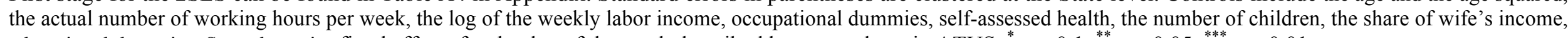
educational dummies, State dummies fixed effects for the day of the week described by respondents in ATUS. ${ }^{*} p<0.1,{ }^{* *} p<0.05,{ }^{* * *} p<0.01$ 
Table 7: Cantril life ladder and interaction between time use and relative working hours among couples (OLS), American Time Use Survey, 2012-2013

\begin{tabular}{|c|c|c|c|c|c|c|}
\hline & \multicolumn{3}{|c|}{ Females } & \multicolumn{3}{|c|}{ Males } \\
\hline & (1) & (2) & (3) & (4) & (5) & (6) \\
\hline Working longer hours than the & $-0.181^{* * * *}$ & 0.273 & 0.268 & -0.039 & -0.134 & -0.136 \\
\hline partner (dummy) & $(0.065)$ & $(0.184)$ & $(0.183)$ & $(0.043)$ & $(0.115)$ & $(0.115)$ \\
\hline Log (household tasks in & & 0.009 & 0.010 & & -0.018 & -0.014 \\
\hline minutes) & & $(0.020)$ & $(0.021)$ & & $(0.018)$ & $(0.019)$ \\
\hline Working longer hours $\times \log$ & & $-0.101^{* * *}$ & $-0.100^{* * *}$ & & 0.024 & 0.025 \\
\hline (household tasks in minutes) & & $(0.037)$ & $(0.037)$ & & $(0.024)$ & $(0.024)$ \\
\hline Log (Working time in minutes) & & & -0.002 & & & -0.002 \\
\hline $\begin{array}{l}\times \log \text { (household tasks in } \\
\text { minutes) }\end{array}$ & & & $(0.001)$ & & & $(0.002)$ \\
\hline Share of wife's income & $\begin{array}{l}-0.088 \\
(0.092)\end{array}$ & $\begin{array}{c}-0.082 \\
(0.094)\end{array}$ & $\begin{array}{c}-0.078 \\
(0.095)\end{array}$ & $\begin{array}{c}0.027 \\
(0.163)\end{array}$ & $\begin{array}{c}0.030 \\
(0.163)\end{array}$ & $\begin{array}{c}0.030 \\
(0.163)\end{array}$ \\
\hline$N$ & 2176 & 2176 & 2176 & 2021 & 2021 & 2021 \\
\hline$R^{2}$ & 0.138 & 0.141 & 0.141 & 0.122 & 0.122 & 0.123 \\
\hline
\end{tabular}

Note: Regressions estimated by OLS. Standard errors are clustered at the State level. Controls include the age and the age squared, the actual number of working hours per week, the log of the weekly labor income, occupational dummies, self-assessed health, the number of children, a relative income dummy, education dummies, State dummies and year dummies. ${ }^{*} p<0.1,{ }^{* *} p<$ $0.05,{ }^{* * *} p<0.01$ 
Table 8: Relative working hours and attitudes towards egalitarianism within the household, BHPS (1997-2007)

\begin{tabular}{|c|c|c|c|c|c|c|}
\hline & \multicolumn{6}{|c|}{ Agree on the following opinion: } \\
\hline & (1) & (2) & (3) & $(4)$ & (5) & (6) \\
\hline & $\begin{array}{c}\text { Family suffers if } \\
\text { mother works full- } \\
\text { time }\end{array}$ & $\begin{array}{c}\text { Woman and } \\
\text { family happier if } \\
\text { she works }\end{array}$ & $\begin{array}{l}\text { Husband and wife } \\
\text { should both } \\
\text { contribute }\end{array}$ & $\begin{array}{c}\text { Full-time job } \\
\text { makes woman } \\
\text { independent }\end{array}$ & $\begin{array}{l}\text { Husband should } \\
\text { earn, wife stay at } \\
\text { home }\end{array}$ & $\begin{array}{c}\text { Children need } \\
\text { father as much as } \\
\text { mother }\end{array}$ \\
\hline \multirow[t]{2}{*}{ Female } & $-1.097^{* * *}$ & $0.512^{* * * *}$ & $0.288^{*}$ & $0.377^{* *}$ & $-0.989^{* * *}$ & $-0.245^{*}$ \\
\hline & $(0.167)$ & $(0.135)$ & $(0.156)$ & $(0.156)$ & $(0.145)$ & $(0.131)$ \\
\hline \multirow[t]{2}{*}{ Wife is working longer hours } & $-0.195^{* * *}$ & $0.054^{*}$ & $0.128^{* * * *}$ & $0.199^{* * *}$ & $-0.136^{* * *}$ & -0.034 \\
\hline & $(0.030)$ & $(0.031)$ & $(0.030)$ & $(0.029)$ & $(0.026)$ & $(0.029)$ \\
\hline Female $\times$ Wife is working & $0.184^{* * *}$ & -0.007 & $-0.093^{*}$ & $-0.091^{*}$ & $0.138^{* * *}$ & 0.006 \\
\hline longer hours & $(0.051)$ & $(0.050)$ & $(0.049)$ & $(0.050)$ & $(0.041)$ & $(0.050)$ \\
\hline \multirow[t]{2}{*}{ Share of wife income } & $-0.022^{* * * *}$ & $0.006^{* * * *}$ & $0.008^{* * *}$ & $0.011^{* * * *}$ & $-0.016^{* * *}$ & -0.001 \\
\hline & $(0.003)$ & $(0.002)$ & $(0.003)$ & $(0.003)$ & $(0.003)$ & $(0.002)$ \\
\hline \multirow[t]{2}{*}{ Female $\times$ Share of wife income } & $0.018^{* * *}$ & $-0.008^{* * *}$ & -0.003 & $-0.006^{*}$ & $0.015^{* * *}$ & 0.002 \\
\hline & $(0.003)$ & $(0.003)$ & $(0.003)$ & $(0.003)$ & $(0.003)$ & $(0.003)$ \\
\hline$N$ & 16408 & 16406 & 16408 & 16409 & 16430 & 16432 \\
\hline$R^{2}$ & 0.066 & 0.014 & 0.042 & 0.050 & 0.099 & 0.020 \\
\hline \multicolumn{7}{|l|}{ Total implied effect: } \\
\hline $\begin{array}{l}\text { Husband working longer hours } \\
\text { than wife }\end{array}$ & Reference & Reference & Reference & Reference & Reference & Reference \\
\hline Husband working fewer/the & $-0.195^{* * *}$ & $0.054^{*}$ & $0.128^{* * *}$ & $0.199^{* * *}$ & $-0.136^{* * *}$ & -0.034 \\
\hline same hours as wife & $(0.030)$ & $(0.031)$ & $(0.030)$ & $(0.029)$ & $(0.026)$ & $(0.029)$ \\
\hline Wife working longer hours than & $-1.107^{* * *}$ & $0.560^{* * *}$ & $0.323^{* *}$ & $0.586^{* * *}$ & $-0.987^{* * *}$ & $-0.273^{* *}$ \\
\hline husband & $(0.171)$ & $(0.139)$ & $(0.160)$ & $(0.160)$ & $(0.148)$ & $(0.135)$ \\
\hline Wife working fewer/the same & $-1.097^{* * *}$ & $0.512^{* * *}$ & $0.288^{*}$ & $0.377^{* *}$ & $-0.989^{* * *}$ & $-0.245^{*}$ \\
\hline hours as husband & $(0.167)$ & $(0.135)$ & $(0.156)$ & $(0.156)$ & $(0.145)$ & $(0.131)$ \\
\hline
\end{tabular}

Note: Regressions estimated by OLS. Standard errors in parentheses. Respondents were asked the questions on their attitudes towards traditional gender identity in Waves 1997, 1999, 2001, 2003, 2005, and 2007. We standardized the outcome variables to have a mean of zero and a standard deviation of 1 . Control variables are the same as Table 5 .

${ }^{*} p<0.1,{ }^{* *} p<0.05,{ }^{* * *} p<0.01$ 
Table 9: Probability of quit at $t+1$ for both genders and the probability of becoming a housewife at $t+1$ for women, BHPS (1996-2008) and SOEP (1995-2012)

\begin{tabular}{|c|c|c|c|c|c|c|}
\hline & \multicolumn{2}{|c|}{ Quit in $\mathrm{t}+1-$ Males } & \multicolumn{2}{|c|}{ Quit in $\mathrm{t}+1-$ Females } & \multicolumn{2}{|c|}{ Leave the LF in $\mathrm{t}+1-$ Females } \\
\hline & $\begin{array}{c}\text { BHPS } \\
\text { (1) }\end{array}$ & $\begin{array}{c}\text { SOEP } \\
(2)\end{array}$ & $\begin{array}{c}\text { BHPS } \\
\text { (3) }\end{array}$ & $\begin{array}{c}\text { SOEP } \\
(4)\end{array}$ & $\begin{array}{c}\text { BHPS } \\
(5)\end{array}$ & $\begin{array}{c}\text { SOEP } \\
(6)\end{array}$ \\
\hline Working longer hours than the partner (dummy) & $\begin{array}{c}0.004 \\
(0.010)\end{array}$ & $\begin{array}{c}0.011^{*} \\
(0.006)\end{array}$ & $\begin{array}{l}0.022^{* *} \\
(0.011)\end{array}$ & $\begin{array}{l}0.017^{\text {*** }} \\
(0.007)\end{array}$ & $\begin{array}{l}0.007^{* *} \\
(0.004)\end{array}$ & $\begin{array}{l}0.010^{* *} \\
(0.005)\end{array}$ \\
\hline Log (Working hours) & $\begin{array}{c}0.003 \\
(0.021)\end{array}$ & $\begin{array}{c}-0.053^{* * *} \\
(0.009)\end{array}$ & $\begin{array}{l}0.061^{* * *} \\
(0.013)\end{array}$ & $\begin{array}{c}-0.019^{* * * *} \\
(0.006)\end{array}$ & $\begin{array}{l}-0.010^{* *} \\
(0.004)\end{array}$ & $\begin{array}{c}0.009^{*} \\
(0.004)\end{array}$ \\
\hline $\log ($ Income $)$ & $\begin{array}{c}-0.015^{*} \\
(0.09)\end{array}$ & $\begin{array}{c}-0.027^{* * *} \\
(0.004)\end{array}$ & $\begin{array}{c}-0.041^{* * *} \\
(0.008)\end{array}$ & $\begin{array}{c}-0.050^{* * *} \\
(0.003)\end{array}$ & $\begin{array}{c}-0.014^{* * *} \\
(0.002)\end{array}$ & $\begin{array}{c}-0.017^{* * *} \\
(0.002)\end{array}$ \\
\hline Share of wife's income & $\begin{array}{c}-0.083 \\
(0.079)\end{array}$ & $\begin{array}{c}-0.037^{* * *} \\
(0.007)\end{array}$ & $\begin{array}{c}0.016 \\
(0.053)\end{array}$ & $\begin{array}{c}-0.002 \\
(0.007)\end{array}$ & $\begin{array}{c}0.016 \\
(0.014)\end{array}$ & $\begin{array}{c}-0.001 \\
(0.005)\end{array}$ \\
\hline$N$ & 20164 & 42199 & 22453 & 42178 & 22453 & 42178 \\
\hline
\end{tabular}

Note: Regressions estimated using probit. Standard errors in parentheses are clustered at the individual level. Controls include the age and the age squared, the log of the actual number of working hours per week, the log of the weekly labor income, occupational dummies, self-assessed health, the number of children, the share of wife's income, education dummies, regional dummies and year fixed effects. ${ }^{*} p<0.1,{ }^{* *} p<0.05,{ }^{* * *} p<0.01$ 
Table 10: Probability of divorce in $\mathbf{t}+1$ and relative working hours in couples

\begin{tabular}{lccccc}
\hline & \multicolumn{2}{c}{ SOEP } & & \multicolumn{2}{c}{ BHPS } \\
\cline { 2 - 3 } \cline { 5 - 6 } & OLS & Probit & & OLS & Probit \\
\hline Wife working longer hours than the & $0.004^{* *}$ & $0.004^{* *}$ & & $0.005^{* *}$ & $0.004^{*}$ \\
husband & $(0.002)$ & $(0.002)$ & & $(0.002)$ & $(0.002)$ \\
Working hours of the wife $(\log )$ & 0.002 & 0.001 & & 0.003 & 0.002 \\
& $(0.002)$ & $(0.000)$ & & $(0.003)$ & $(0.002)$ \\
Share of the wife income & $0.011^{* *}$ & $0.011^{* * *}$ & & $0.009^{* * *}$ & $0.008^{* * *}$ \\
& $(0.005)$ & $(0.004)$ & & $(0.003)$ & $(0.003)^{* * *}$ \\
Family income $(\log )$ & $-0.004^{* * *}$ & $-0.003^{* * *}$ & & $-0.006^{* * *}$ & $-0.005^{* * *}$ \\
& $(0.001)$ & $(0.001)$ & & $(0.002)$ & $(0.002)^{* * *}$ \\
Age of the wife & $-0.001^{* * *}$ & $-0.001^{* * *}$ & & $-0.001^{* * *}$ & $-0.001^{* * *}$ \\
& $(0.000)$ & $(0.000)$ & & $(0.000)$ & $(0.000)$ \\
Age of the husband & -0.001 & -0.001 & & -0.000 & -0.000 \\
& $(0.001)$ & $(0.001)$ & & $(0.000)$ & $(0.000)$ \\
Health of the wife & -0.001 & -0.001 & & $-0.002^{* * *}$ & $-0.002^{* * *}$ \\
& $(0.000)$ & $(0.001)$ & & $(0.001)$ & $(0.000)$ \\
Health of the husband & -0.000 & -0.000 & & $-0.002^{* * *}$ & $-0.001^{* * *}$ \\
& $(0.000)$ & $(0.000)$ & & $(0.000)$ & $(0.000)$ \\
Number of children & $-0.002^{* *}$ & $-0.002^{* *}$ & & -0.003 & -0.003 \\
& $(0.001)$ & $(0.001)$ & & $(0.005)$ & $(0.004)$ \\
\hline$N$ & 42626 & 42626 & & 17969 & 17969 \\
\hline
\end{tabular}

Note: Standard errors in parentheses are clustered at the household level. The sample includes individuals who reported to be married at $t$. Controls include the number of children, a relative income dummy and year fixed effects. ${ }^{*} p<0.1,{ }^{* *} p$ $<0.05,{ }^{* * *} p<0.01$ 


\section{Appendix}

Table 1A: Descriptive statistics, American Time Use Survey 2012-2013

\begin{tabular}{|c|c|c|c|c|c|c|}
\hline & \multicolumn{3}{|c|}{ Husbands working: } & \multicolumn{3}{|c|}{ Wives working: } \\
\hline & $\begin{array}{c}\text { More than } \\
\text { wife }\end{array}$ & $\begin{array}{l}\text { As much as } \\
\text { wife }\end{array}$ & $\begin{array}{c}\text { Less than } \\
\text { wife }\end{array}$ & $\begin{array}{c}\text { More than } \\
\text { husband }\end{array}$ & $\begin{array}{l}\text { As much as } \\
\text { husband }\end{array}$ & $\begin{array}{l}\text { Less than } \\
\text { husband }\end{array}$ \\
\hline \multirow[t]{2}{*}{ Cantril life ladder } & 7.388 & 7.438 & 7.324 & 7.359 & 7.585 & 7.602 \\
\hline & $(1.625)$ & $(1.573)$ & $(1.749)$ & $(1.670)$ & $(1.542)$ & $(1.580)$ \\
\hline \multirow[t]{2}{*}{ Working Hours } & 48.29 & 40.85 & 35.59 & 46.72 & 40.80 & 30.23 \\
\hline & $(10.58)$ & $(3.756)$ & (11.18) & $(8.656)$ & $(4.062)$ & (11.67) \\
\hline \multirow[t]{2}{*}{ Weekly Earnings } & 1190.7 & 1098.0 & 807.5 & 1076.7 & 937.5 & 615.9 \\
\hline & $(823.2)$ & $(678.6)$ & $(719.5)$ & $(731.8)$ & $(577.3)$ & $(562.1)$ \\
\hline \multirow[t]{2}{*}{ Self-assessed Health } & 2.261 & 2.315 & 2.242 & 2.156 & 2.229 & 2.206 \\
\hline & $(0.873)$ & $(0.888)$ & $(0.944)$ & $(0.899)$ & $(0.911)$ & $(0.910)$ \\
\hline \multirow[t]{2}{*}{ Age } & 42.85 & 42.53 & 43.09 & 42.56 & 41.55 & 41.69 \\
\hline & $(9.024)$ & $(9.025)$ & $(9.960)$ & $(9.394)$ & $(9.135)$ & $(9.154)$ \\
\hline \multirow[t]{2}{*}{ Partner's working hours } & 30.32 & 40.85 & 48.18 & 34.29 & 40.80 & 47.82 \\
\hline & (11.47) & $(3.756)$ & $(10.95)$ & $(11.02)$ & $(4.062)$ & $(10.84)$ \\
\hline \multirow[t]{2}{*}{ Partner's weekly earnings } & 615.3 & 945.3 & 1016.6 & 799.0 & 1036.7 & 1147.0 \\
\hline & $(542.6)$ & $(597.5)$ & $(760.7)$ & $(684.0)$ & $(699.6)$ & $(796.2)$ \\
\hline \multirow[t]{2}{*}{ Share of wife's income } & 0.344 & 0.455 & 0.537 & 0.560 & 0.466 & 0.348 \\
\hline & $(0.156)$ & $(0.133)$ & $(0.154)$ & $(0.162)$ & $(0.129)$ & $(0.157)$ \\
\hline \multirow[t]{2}{*}{ Household annual income } & 3.477 & 3.544 & 3.402 & 3.370 & 3.503 & 3.459 \\
\hline & $(0.751)$ & $(0.677)$ & $(0.857)$ & $(0.843)$ & $(0.736)$ & $(0.777)$ \\
\hline \multirow[t]{2}{*}{ Number of Children } & 1.370 & 1.208 & 1.107 & 1.130 & 1.150 & 1.406 \\
\hline & $(1.098)$ & $(1.065)$ & $(1.064)$ & $(1.091)$ & $(1.024)$ & $(1.080)$ \\
\hline$N$ & 975 & 802 & 244 & 270 & 833 & 1071 \\
\hline
\end{tabular}

Note: Standard deviations are in parentheses. 
Table 2A: U-index and relative working hours by gender, American Time Use Survey 2012-2013

\begin{tabular}{|c|c|c|c|c|}
\hline & & $\begin{array}{c}\text { U-index } 3 \\
\text { dimensions }\end{array}$ & $\begin{array}{c}\text { U-index } 4 \\
\text { dimensions }\end{array}$ & $\begin{array}{c}\text { U-index } 6 \\
\text { dimensions }\end{array}$ \\
\hline \multirow{3}{*}{ Males } & $\begin{array}{l}\text { Working fewer } \\
\text { hours than the } \\
\text { partner }\end{array}$ & $\begin{array}{c}0.136 \\
(0.016)\end{array}$ & $\begin{array}{c}0.184 \\
(0.013)\end{array}$ & $\begin{array}{c}0.068 \\
(0.007)\end{array}$ \\
\hline & $\begin{array}{l}\text { Working as } \\
\text { much as the } \\
\text { partner }\end{array}$ & $\begin{array}{c}0.077 \\
(0.011)\end{array}$ & $\begin{array}{c}0.115 \\
(0.010)\end{array}$ & $\begin{array}{c}0.057 \\
(0.008)\end{array}$ \\
\hline & $\begin{array}{l}\text { Working longer } \\
\text { hours than the } \\
\text { partner }\end{array}$ & $\begin{array}{c}0.148 \\
(0.008)\end{array}$ & $\begin{array}{c}0.194 \\
(0.013)\end{array}$ & $\begin{array}{c}0.102 \\
(0.009)\end{array}$ \\
\hline \multirow{3}{*}{ Females } & $\begin{array}{l}\text { Working fewer } \\
\text { hours than the } \\
\text { partner }\end{array}$ & $\begin{array}{c}0.101 \\
(0.006)\end{array}$ & $\begin{array}{c}0.168 \\
(0.010)\end{array}$ & $\begin{array}{c}0.091 \\
(0.005)\end{array}$ \\
\hline & $\begin{array}{l}\text { Working as } \\
\text { much as the } \\
\text { partner }\end{array}$ & $\begin{array}{c}0.168 \\
(0.011)\end{array}$ & $\begin{array}{c}0.261 \\
(0.013)\end{array}$ & $\begin{array}{c}0.152 \\
(0.007)\end{array}$ \\
\hline & $\begin{array}{l}\text { Working longer } \\
\text { hours than the } \\
\text { partner }\end{array}$ & $\begin{array}{c}0.214 \\
(0.014)\end{array}$ & $\begin{array}{c}0.344 \\
(0.023)\end{array}$ & $\begin{array}{c}0.252 \\
(0.022)\end{array}$ \\
\hline
\end{tabular}

Note: Standard errors are in parentheses. 
Table 3A: Cantril life ladder and relative working hours among couples with different sets of controls: OLS, American Time Use Survey 2012-2013

\begin{tabular}{|c|c|c|c|c|c|c|c|c|}
\hline & \multicolumn{4}{|c|}{ Females } & \multicolumn{4}{|c|}{ Males } \\
\hline & $\begin{array}{l}\text { Without } \\
\text { controls }\end{array}$ & $\begin{array}{c}\text { With job } \\
\text { characteristics }\end{array}$ & $\begin{array}{c}\text { With socio- } \\
\text { demographics }\end{array}$ & $\begin{array}{c}\text { Complete } \\
\text { specification }\end{array}$ & $\begin{array}{l}\text { Without } \\
\text { controls }\end{array}$ & $\begin{array}{c}\text { With job } \\
\text { characteristics }\end{array}$ & $\begin{array}{c}\text { With socio- } \\
\text { demographics }\end{array}$ & $\begin{array}{c}\text { Complete } \\
\text { specification }\end{array}$ \\
\hline $\begin{array}{l}\text { Working longer } \\
\text { hours than the } \\
\text { partner }\end{array}$ & $\begin{array}{l}-0.158^{* *} \\
(0.065)\end{array}$ & $\begin{array}{c}-0.161^{* *} \\
(0.063)\end{array}$ & $\begin{array}{c}-0.184^{* * *} \\
(0.065)\end{array}$ & $\begin{array}{c}-0.181^{* * *} \\
(0.065)\end{array}$ & $\begin{array}{l}-0.042 \\
(0.043)\end{array}$ & $\begin{array}{l}-0.046 \\
(0.039)\end{array}$ & $\begin{array}{l}-0.033 \\
(0.043)\end{array}$ & $\begin{array}{l}-0.039 \\
(0.043)\end{array}$ \\
\hline$N$ & 2176 & 2176 & 2176 & 2176 & 2021 & 2021 & 2021 & 2021 \\
\hline$R^{2}$ & 0.011 & 0.021 & 0.126 & 0.138 & 0.008 & 0.017 & 0.119 & 0.122 \\
\hline
\end{tabular}

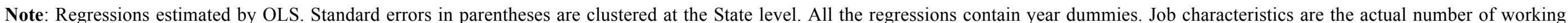

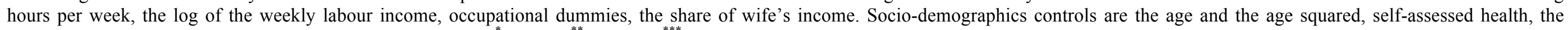
number of children, educational dummies and State dummies. ${ }^{*} p<0.1,{ }^{* *} p<0.05,{ }^{* * *} p<0.01$ 